\title{
MODE OF ACTION OF A BACTERIOCIN FROM ERWINIA CAROTOVORA III. PROPERTIES OF PHOSPHOLIPASE A OF ERWINIA CAROTOVORA AND ITS INVOLVEMENT IN PHOSPHOLIPID DEGRADATION CAUSED BY CAROTOVORICIN
}

\author{
YOSHIFUMI ITOH,${ }^{1}$ TOSHIHARU IWATA, KAZUO IZAKI, \\ AND HAJIME TAKAHASHI ${ }^{2}$ \\ Department of Agricultural Chemistry, Faculty of Agriculture, \\ Tohoku University, Sendai 980
}

(Received February 3, 1981)

\begin{abstract}
Phospholipase A in the outer membrane of Erwinia carotovora 645ArT was found to be activated by various detergents such as cholate, deoxycholate and Triton X-100, and methanol. The enzyme was inhibited by ethylenediaminetetraacetic acid, and $\mathrm{Ca}^{2+}$ was required for the enzyme activity. The enzyme hydrolyzed phosphatidylethanolamine and phosphatidylglycerol to form nearly equimolar amounts of free fatty acids and lysophospholipids. Cardiolipin, however, was not susceptible to the enzyme. In a mutant strain deficient in the phospholipase A activity, the rate of degradation of membrane phospholipid caused by carotovoricin Er, a bacteriocin from Erwinina carotovora strain Er, declined to about $1 / 10$ of that of the parent strain under similar conditions. Lysis caused by carotovoricin Er also diminished in the phospholipase Adeficient mutant. These results imply that carotovoricin Er provokes an activation of phospholipase $\mathrm{A}$ in sensitive cells, and subsequently, degradation of membane phospholipid and cell lysis result. Phospholipase A-deficient mutant, however, still retained sensitivity to killing activity of carotovoricin Er. Hence, it could be concluded that activation of phospholipase $\mathrm{A}$ is not related to the primary bactericidal action of the bacteriocin.
\end{abstract}

Bacteriocins are bactericidal proteinaceous substances produced by certain bacteria(1). Carotovoricin Er, a bacteriocin from Erwinia carotovora strain

1 Present address: Department of Bacteriology, Shinshu University School of Medicine, Matsumoto 390.

2 Author to whom reprint requests should be addressed. 
$\mathrm{Er}$, is a species of high molecular weight bacteriocin according to the classification of BRADLEY (2), and its structure consists of a contractible sheath, a core surrounded with the sheath and fibers, quite closely resembling that of a tail part of bacteriophage (3).

In previous reports, we demonstrated that carotovoricin $\mathrm{Er}$ caused prompt and extensive cell lysis (4) and membrane phospholipid degradation (5) of a sensitive strain. Our previous results suggested that phospholipase A of a sensitive strain might be a major cause of the phospholipid degradation and lysis of the sensitive cells treated with carotovoricin Er. From the examination of the morphology of native carotovoricin Er and carotovoricin Er adsorbed to the cell surface of a sensitive strain, infection of the bacteriocin is considered to proceed as follows: i) Specific interaction of the tips of the bacteriocin fibers with bacteriocin receptors on the cell surface. ii) Contraction of the sheath after adsorption of the fibers onto the receptor. iii) Interaction of the core with the cell envelope. During the course of infection, the fibers and core of the bacteriocin would interact with the outer membrane of sensitive cells in a specific manner. It would be possible to speculate that at the early stages of the infection, the bacteriocin might provoke some structural alteration of the cell envelope, or disturbance of enzyme systems in the cell envelope.

We describe in this report some properties of phospholipase A of E. carotovora $645 \mathrm{ArT}$, a strain sensitive to carotovoricin $\mathrm{Er}$, which was able to be activated by treatment with the bacteriocin, and isolation of mutants deficient in phospholipase A activity. Phospholipid degradation in a phospholipase A-deficient mutant was considerably reduced compared to the wild strain when both strains were treated with carotovoricin Er. This result suggests that phospholipid degradation in carotovoricin Er-treated cells was caused mainly by the action of phospholipase A and that treatment of the sensitive cells by carotovoricin Er caused an activation of phospholipase A which exists in a latent form in the normal cells.

\section{MATERIALS AND METHODS}

Bacterial strains. E. carotovora Er (AMS 6082) was used as a bacteriocinogenic strain and E. carotovora $645 \mathrm{Ar}$, which was kindly supplied by Prof. $\mathrm{H}$. Tsuyama of the Faculty of Agriculture, Iwate University, Morioka, was used as a sensitive strain to carotovoricin $\operatorname{Er}(3-5)$. E E carotovora $645 \mathrm{ArT}(5)$ was a thyminerequiring mutant derived from $E$. carotovora $645 \mathrm{Ar}$. E. coli K1061, a mutant requiring unsaturated fatty acid for growth, was kindly supplied from Dr. H. R. Kaback of the Roche Institute for Molecular Biology, Nutley, New Jersey, U.S.A.

Medium and growth conditions. The organisms were usually grown in M9 minimal medium supplemented with $0.2 \%$ of glucose and casein acid hydrolysate respectively, or nutrient broth at $30^{\circ}$ with reciprocal shaking $(120 \mathrm{cycles} / \mathrm{min})$ as described previously (3). Nutrient agar was made by solidifying the nutrient broth 
with $1.5 \%$ agar.

Preparation of carotovoricin Er. Carotovoricin Er was purified from the culture of E. carotovora Er induced with $0.2 \mu \mathrm{g}$ per ml of mitomycin-C (Kyowa Hakko Kogyo Co., Ltd., Tokyo) and prepared for use as described previously $(3,4)$.

Preparation of ${ }^{14} \mathrm{C}$-labeled phospholipids. ${ }^{14} \mathrm{C}$-Phospholipids were extracted from the cells of Escherichia coli K12 W2252 grown in the presence of $0.1 \mu \mathrm{Ci}$ per $\mathrm{ml}$ of $\left[1-{ }^{14} \mathrm{C}\right]$ acetate (Specific activity $58 \mathrm{mCi} / \mathrm{mmol}$, The Radiochemical Centre, Amersham, England) according to the procedure of BLIGH and DYER (6). ${ }^{14} \mathrm{C}$ Phosphatidylethanolamine and ${ }^{14} \mathrm{C}$-cardiolipin were purified by silicic acid column chromatography (7). ${ }^{14} \mathrm{C}$-Phosphatidylglycerol was further purified by DEAEcellulose column chromatography $(8)$, because the fraction of phosphatidylglycerol from silicic acid column chromatography contained a significant amount of phosphatidylethanolamine. Specific radioactivities and purities of ${ }^{14} \mathrm{C}$-phosphatidylethanolamine, ${ }^{14} \mathrm{C}$-phosphatidylglycerol, and ${ }^{14} \mathrm{C}$-cardiolipin were $352 \mathrm{dpm} / \mathrm{nmol}$ $(98 \%), 382 \mathrm{dpm} / \mathrm{nmol}(95 \%)$, and $780 \mathrm{dpm} / \mathrm{nmol}(97 \%)$, respectively. [1- $\left.{ }^{14} \mathrm{C}\right]-$ acyl-glycerylphosphorylethanolamine was prepared from ${ }^{14} \mathrm{C}$-phosphatidylethanolamine $\left(48 \mu \mathrm{mol}\right.$ ) by treatment with phospholipase $\mathrm{A}_{2}$ from Vipera russelli (Sigma Chemical Co., St. Louis, U.S.A.) and purified on Silica gel thin-layer (Silica gel 60, E. Merck, Darmstat, West Germany) chromatography with chloroform-methanolwater $(65: 25: 4, \mathrm{v} / \mathrm{v})$ as a solvent. Purity of $\left[1-{ }^{14} \mathrm{C}\right]$-acyl-glycerylphosphorylethanolamine was $90 \%$, and its specific radioactivity $170 \mathrm{dpm} / \mathrm{nmol}$. Purity of ${ }^{14} \mathrm{C}$ phospholipids was determined by counting radioactivities on the Silica gel plate developed with appropriate solvent systems. Chemical amount of phospholipid was determined by colorimetric analysis of phosphate as described by BARTLETT (9) using $\alpha$-glycerophosphate as a standard.

Preparation of enzyme. Mid-log phase cells grown in M9-glucose-casamino acid medium $(200 \mathrm{ml})$ were harvested and washed twice with $20 \mathrm{ml}$ of ice-cold $0.02 \mathrm{M}$ tris(hydroxymethyl)-aminomethane (Tris)- $\mathrm{HCl}$ buffer containing $0.15 \mathrm{M} \mathrm{NaCl}$, $\mathrm{pH} \mathrm{7.2,} \mathrm{and} \mathrm{suspended} \mathrm{in} 20 \mathrm{ml}$ of $0.05 \mathrm{~m}$ Tris- $\mathrm{HCl}$ buffer, $\mathrm{pH} \mathrm{7.2.} \mathrm{The} \mathrm{cells} \mathrm{were}$ disrupted by a Kubota sonicator at $10 \mathrm{kHz}$ for $3 \mathrm{~min}$. After centrifugation at $5,000 \times g$ for $10 \mathrm{~min}$ to remove intact cells and cell debris, the supernatant was used for enzyme preparation. Protein concentration was determined by the method of LOWRY et al. (10) using bovine serum albumin as standard.

Assay of phospholipase $A$ and lysophospholipase. Unless otherwise noted, phospholipase A was assayed in the reaction mixture containing $0.025 \mathrm{M}$ Tris- $\mathrm{HCl}$ buffer, $\mathrm{pH} 7.2,{ }^{14} \mathrm{C}$-phosphatidylethanolamine (100 nmol), $5 \mathrm{~mm} \mathrm{CaCl}_{2}, 50 \%$ methanol and $0.1 \mathrm{ml}$ of enzyme preparation in a total volume of $2 \mathrm{ml}$. The mixture was incubated at $30^{\circ}$ for $30 \mathrm{~min}$, and the reaction was terminated by adding $1 \mathrm{ml}$ of methanol and $4 \mathrm{ml}$ of chloroform. After vigorous mixing for $30 \mathrm{sec}$, the mixture was centrifuged at $2,000 \times g$ for $5 \mathrm{~min}$ to separate the two layers. The lower chloroform phase was evaporated to dryness under reduced pressure at $30^{\circ}$, and the residue was dissolved in a small volume of chloroform-methanol (2:1, 
$\mathrm{v} / \mathrm{v}$ ) and spotted on the Silica gel thin-layer plate. Chromatography was carried out with chloroform-methanol-acetic acid $(65: 25: 10, \mathrm{v} / \mathrm{v})$ as a solvent. The reaction mixture for lysophospholipase assay contained $0.05 \mathrm{M}$ glycine- $\mathrm{NaOH}$ buffer, $\mathrm{pH}$ $10.0,\left[1-{ }^{14} \mathrm{C}\right]$-acyl-glycerylphosphorylethanolamine $(100 \mathrm{nmol})$ and $0.1 \mathrm{ml}$ of enzyme preparation in a total volume of $1 \mathrm{ml}$. Incubation was done at $30^{\circ}$ for $30 \mathrm{~min}$, and the reaction was terminated by adding $6 \mathrm{ml}$ of chloroform-methanol $(2: 1, \mathrm{v} / \mathrm{v})$. Lipids were extracted as described above and separated on the Silica gel thin-layer plate with petroleum ether-diethyl ether-formic acid $(55: 45: 1.5, \mathrm{v} / \mathrm{v})$ as a solvent. Each area on the thin-layer plates corresponding to free fatty acid, lysophosphatidylethanolamine or phosphatidylethanolamine was scraped off and their radioactivities were measured with a Packard Tri-Carb 3385 liquid scintillation spectrometer in a toluene scintillation fluid. One unit was defined as the amount of the enzyme releasing $1 \mathrm{nmol}$ free fatty acid per min under these conditions.

Isolation of outer membrane. Middle log-phase cells of $E$. carotovora 645ArT grown in 1 liter of M9-glucose-casamino acid medium were harvested and washed once with $100 \mathrm{ml}$ of ice-cold $10 \mathrm{~mm} \mathrm{~N}$-2-hydroxylethylpiperazine- $\mathrm{N}^{\prime}$-ethanesulfonic

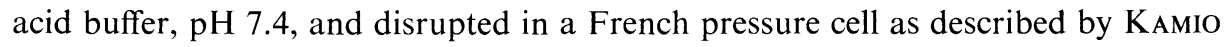
and NiKaido (11). The membrane fraction was subjected to sucrose density gradient centrifugation $(I I)$ to separate the outer membrane from the inner. Adenosinetriphosphatase (ATPase), a marker enzyme of the inner membrane, was assayed in $1 \mathrm{ml}$ of the reaction mixture containing $20 \mathrm{~mm}$ Tris- $\mathrm{HCl}$ buffer, $\mathrm{pH} \mathrm{9.0,}$ $2.5 \mathrm{~mm} \mathrm{ATP}-\mathrm{Na}_{2}$ and $1 \mathrm{~mm} \mathrm{MgCl}_{2}$. The reaction was carried out at $30^{\circ}$ for $20 \mathrm{~min}$ and terminated by adding $0.1 \mathrm{ml}$ of $0.5 \mathrm{~N} \mathrm{HCl}$. Inorganic phosphate liberated was determined by the method of TAUSKY and SHORR (12).

Isolation of a mutant deficient in phospholipase A. Properties of a major phospholipase A of E. carotovora 645ArT were quite similar to those of E. coli detergent-resistant (dr)-phospholipase A (13). Therefore, the procedures developed for the isolation of mutants defective in dr-phospholipase A activity of E. coli by OHKI et al. (13) were applied to isolate a mutant deficient in phospholipase A of E. carotovora $645 \mathrm{ArT}$, with a slight modification.

The mutagenized cells of E. carotovora $645 \mathrm{ArT}$ with $\mathrm{N}$-methyl-N'-nitro-Nnitrosoguanidine according to the method of ADELBERG et al. (14) were spread on nutrient agar medium (about 80 colonies/plate), and the plates were incubated at $30^{\circ}$ for $36 \mathrm{hr}$. The colonies were transferred to fresh nutrient agar plates by the replica method, and these plates were then incubated at $30^{\circ}$ for $30 \mathrm{hr}$. Soft agar $(3 \mathrm{ml})$ was carefully poured over the colonies on the replicated plates, which were incubated at $30^{\circ}$ overnight. Soft agar contained M9-minimal medium, $0.5 \%$ sodium dodecylsulfate (SDS), $5 \%$ ethanol, $2 \times 10^{8}$ cells of $E$. coli $\mathrm{K} 1061$ per ml and $0.5 \%$ agar. The colonies on the original plates corresponding to the colonies which could not support growth of the unsaturated fatty acid auxotroph $E$. coli were isolated and purified. Among $10^{4}$ colonies tested, 3 colonies were isolated and confirmed to be mutants deficient in phospholipase A. 


\section{RESULTS}

\section{Properties of phospholipase $A$ and lysophospholipase}

No phospholipase A activity could be detected on assay in the absence of detergent or methanol in the reaction mixture using ${ }^{14} \mathrm{C}$-phosphatidylethanolamine as a substrate. As shown in Fig. 1 and Table 1, however, considerable activity was found if the reaction mixture was supplemented with an adequate concentration of

Table 1. Effects of $\mathrm{Ca}^{2+}$, methanol and EDTA on phospholipase A activity.

Assay system

A

B
Additions or omissions

None

$+\mathrm{CaCl}_{2}(5 \mathrm{~mm})$

+ EDTA (5 mm)

Complete

- Methanol

$-\mathrm{CaCl}_{2},+$ EDTA (1 mM)
Enzyme activity

$\begin{array}{cl}\text { unit/mg protein } & (\%) \\ 26.6 & (100) \\ 42.1 & (158) \\ 1.4 & (5) \\ 11.9 & (100) \\ 0.3 & (2.5) \\ 0.9 & (7.6)\end{array}$

The reaction mixture of assay system A contained $50 \mathrm{~mm}$ Tris- $\mathrm{HCl}$ buffer, $\mathrm{pH} 7.2,0.5 \%$ sodium cholate, $100 \mathrm{nmol}$ of ${ }^{14} \mathrm{C}$-phosphatidylethanolamine and enzyme preparation (50 $\mu \mathrm{g}$ protein) in a total volume of $1 \mathrm{ml}$. The complete composition of assay system B was described in MATERIALS AND METHODS. These mixtures were incubated at $30^{\circ}$ for $30 \mathrm{~min}$. Phospholipase A activity was determined as described in MATERIALS AND METHODS.

EDTA, ethylenediaminetetraacetic acid.

cholate $(0.5 \%)$ or methanol $(50 \%)$. Similar activation of phospholipase A was also found with the addition of Triton X-100 $(0.2 \%)$, deoxycholate $(0.5 \%)$ or SDS $(0.1 \%)$ instead of methanol or cholate. $\mathrm{Ca}^{2+}$ stimulated phospholipase $\mathrm{A}$ about 1.5-fold, and ethylenediaminetetraacetic acid (EDTA) reduced the activity to 5-8\% of the control (Table 1). In contrast to phospholipase A activity, lysophospholipase of E. carotovora 645ArT was inhibited by various detergents such as cholate, deoxycholate, Triton X-100 and SDS, and methanol. EDTA partially inhibited the enzyme activity (about $60 \%$ ). The results are shown in Table 2. pH optima for phospholipase A and lysophospholipase were $\mathrm{pH} 7.2$ and $\mathrm{pH} 10.0$, respectively. In our assay conditions for phospholipase $\mathrm{A}$, nearly equimolar amounts of fatty acid and lysophosphatidylethanolamine were formed from ${ }^{14} \mathrm{C}$-phosphatidylethanolamine, as shown in Fig. 2. Similar time courses of fatty acid and lysophosphatidylglycerol formation were obtained using ${ }^{14} \mathrm{C}$-phosphatidylglycerol as a substrate. These results indicate that lysophospholipid formed by phospholipase A would not be appreciably hydrolyzed due to the inhibitory action of detergents and methanol on lysophospholipase activity.

In carotovoricin Er-treated cells, phosphatidylethanolamine (PE) and phosphatidylglycerol (PG) were deacylated specifically, while no deacylation of cardiolipin (CL) was observed (5). If deacylation of PE and PG was caused by phospholipase 


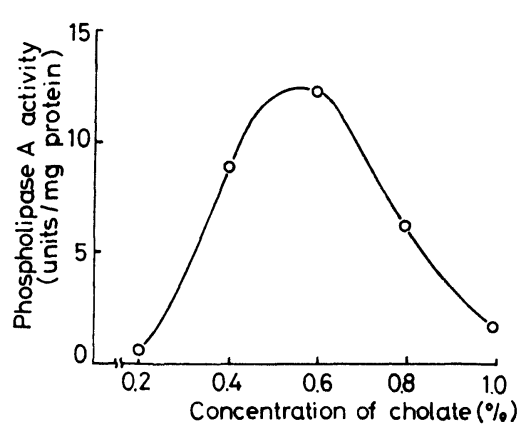

Fig. 1.

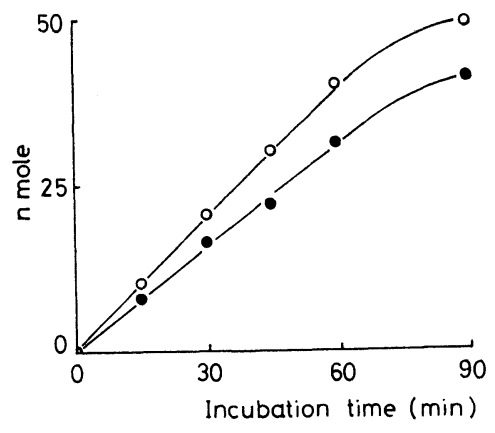

Fig. 2.

Fig. 1. Activation of phospholipase A by cholate.

The reaction mixture $(1 \mathrm{ml})$ contained $0.05 \mathrm{M}$ Tris- $\mathrm{HCl}$ buffer, $\mathrm{pH} 7.2,100 \mathrm{nmol}$ of ${ }^{14} \mathrm{C}$-phosphatidylethanolamine, sodium cholate (final concentrations of zero to $1.0 \%$ ) and enzyme preparation $(0.1 \mathrm{mg}$ protein) in a total volume of $1 \mathrm{ml}$. After incubation at $30^{\circ}$ for $30 \mathrm{~min}, 6 \mathrm{ml}$ of chloroform-methanol $(2: 1, \mathrm{v} / \mathrm{v})$ was added to the mixtures and lipids were extracted. The amounts of free fatty acids were determined as described in MATERIALS AND METHODS.

Fig. 2. Time course of formation of free fatty acid and lysophosphatidylethanolamine from ${ }^{14} \mathrm{C}$-phosphatidylethanolamine by phospholipase $\mathrm{A}$.

The standard reaction mixture with enzyme preparation $(50 \mu \mathrm{g}$ protein) was used. After incubation at $30^{\circ}$ for a desired time, the reaction was terminated. The radioactivities of free fatty acid and lysophosphatidylethanolamine were determined as described in MATERIALS AND METHODS. O, free fatty acid; $\bullet$ lysophosphatidylethanolamine.

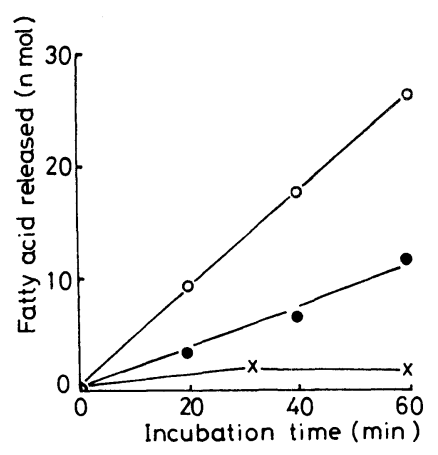

Fig. 3. Substrate specificity of phospholipase A from E. carotovora 645ArT. The enzyme activity ( $26 \mu \mathrm{g}$ protein) was assayed using ${ }^{14} \mathrm{C}$-phosphatidylethanolamine ( $\bigcirc),{ }^{14} \mathrm{C}$-phosphatidylglycerol $(\bullet)$, or ${ }^{14} \mathrm{C}$-cardiolipin $(\times)$ as substrate.

A in the cells treated with carotovoricin Er, the enzyme should hydrolyze only PE and PG. Figure 3 shows that phospholipase A, indeed, hydrolyzed only PE and PG, but not CL.

Phospholipase A of E. carotovora $645 \mathrm{ArT}$ was resistant to heat-treatment and 
only $8 \%$ of original activity was lost by heating at $100^{\circ}$ for $10 \mathrm{~min}$, and even a slight activation was observed by heat-treatment at $40^{\circ}$ to $80^{\circ}$ for $10 \mathrm{~min}$. On the other hand, about $30 \%$ of original lysophospholipase activity was lost by heat-treatment at $100^{\circ}$ for $10 \mathrm{~min}$. These properties of the phospholipase $\mathrm{A}$ of this organism are quite similar to those of $\mathrm{dr}$-phospholipase $\mathrm{A}$ of $E$. coli with respect to resistance to detergent and heat, and $\mathrm{Ca}^{2+}$ requirement $(15,16)$. Dr-phospholipase A of $E$. coli has been found to be located in the outer membrane (16-18). We hence examined the location of phospholipase A of E. carotovora 645ArT. Most of the phospholipase A activity of this organism was found in the membrane fraction obtained by centrifugation at $100,000 \times g$ for $45 \mathrm{~min}$ (Table 3 ), and $82 \%$ of activity in the membrane fraction was recovered in the outer membrane fraction which was free from ATPase (Table 4). Lysophospholipase was also mainly recovered in the membrane fraction. Significant activity $(32 \%)$, however, was found in the cytoplasmic fraction (Table 3).

Table 2. Inhibitory effect of detergents, EDTA and methanol on lysophospholipase.

\begin{tabular}{lcc} 
& \multicolumn{2}{c}{ Lysophospholipase } \\
\cline { 2 - 3 } \multicolumn{1}{c}{ Additions } & unit/mg protein & $(\%)$ \\
None & 25.5 & $(100)$ \\
Cholate $(0.2 \%)$ & 16.7 & $(65)$ \\
Deoxycholate $(0.2 \%)$ & 1.7 & $(7)$ \\
Triton X-100 $(0.2 \%)$ & 4.1 & $(16)$ \\
SDS $(0.2 \%)$ & 1.1 & $(4)$ \\
EDTA $(5 \mathrm{~mm})$ & 9.4 & $(38)$ \\
Methanol $(50 \%)$ & 0.7 & $(3)$
\end{tabular}

Lysophospholipase activity was measured in the reaction mixture described in MATERIALS AND METHODS with the additions noted.

Table 3. Location of phospholipase A and lysophospholipase.

\begin{tabular}{|c|c|c|c|c|}
\hline \multirow[b]{2}{*}{ Enzyme source } & \multicolumn{2}{|c|}{ Phospholipase A } & \multicolumn{2}{|c|}{ Lysophospholipase } \\
\hline & $\begin{array}{l}\text { unit } / \mathrm{mg} \\
\text { protein }\end{array}$ & $\begin{array}{l}\text { total } \\
\text { activity } \\
\text { (unit) }\end{array}$ & $\begin{array}{l}\text { unit } / \mathrm{mg} \\
\text { protein }\end{array}$ & $\begin{array}{l}\text { total } \\
\text { activity } \\
\text { (unit) }\end{array}$ \\
\hline Whole sonicate & 14.5 & 181 & 27.1 & 423 \\
\hline $\begin{array}{l}\text { Supernatant after } \\
\text { centrifugation }\end{array}$ & 0.4 & 4 & 12.4 & 136 \\
\hline $\begin{array}{l}\text { Precipitate after } \\
\text { centrifugation }\end{array}$ & 37.9 & 125 & 92.2 & 203 \\
\hline
\end{tabular}

Exponentially growing cells of E. carotovora $645 \mathrm{ArT}$ were disrupted by sonication. The sonicate was centrifuged at $100,000 \times g$ for $45 \mathrm{~min}$. The precipitate obtained was dispersed in $0.05 \mathrm{M}$ Tris- $\mathrm{HCl}$ buffer, $\mathrm{pH}$ 7.2. Phospholipase A and lysophospholipase activities in each preparation were assayed. 
Table 4. Location of phospholipase A.

\begin{tabular}{lcc}
\multicolumn{1}{c}{ Fraction } & $\begin{array}{c}\text { Phospholipase A } \\
\text { (unit) }\end{array}$ & $\begin{array}{c}\text { ATPase } \\
\text { (unit) }^{a}\end{array}$ \\
Total membrane & 80.4 & 2.3 \\
Outer membrane & 65.9 & 0 \\
Inner membrane & 8.9 & 1.8
\end{tabular}

$a$ One unit of ATPase was the amount of the enzyme liberating $1 \mu \mathrm{mol}$ of inorganic phosphate per min under our assay conditions.

Table 5. Phospholipase A and lysophospholipase activities of E. carotovora 645ArT and its phospholipase A-deficient mutants.

\begin{tabular}{|c|c|c|c|c|}
\hline \multirow{2}{*}{ Strain } & \multicolumn{2}{|c|}{ Phospholipase A } & \multicolumn{2}{|c|}{ Lysophospholipase } \\
\hline & unit/mg protein & $(\%)$ & unit/mg protein & $(\%)$ \\
\hline E. carotovora $645 \mathrm{ArT}$ & 11.1 & $(100)$ & 29.0 & $(100)$ \\
\hline Mutant No. 1 & 0.1 & $(1.0)$ & 10.0 & ( 34$)$ \\
\hline No. 2 & 0.2 & $(1.8)$ & 10.4 & $(38)$ \\
\hline No. 3 & 0 & $(0)$ & 7.0 & ( 24) \\
\hline
\end{tabular}

The organisms were grown to middle log-phase in M9-glucose-casamino acid medium. Preparation of enzyme and enzyme assay were done as described in MATERIALS AND METHODS.

\section{Isolation of a mutant deficient in phospholipase $A$}

In order to ascertain that phospholipase A of E. carotovora 645 ArT is involved in the degradation of phospholipids induced by carotovoricin Er, we isolated mutants deficient in phospholipase A activity. The isolation of the mutant was carried out at $30^{\circ}$, the optimal growth temperature for this organism. The colonies which did not support the indicator strain were detected after growth at $30^{\circ}$. They showed a defect in phospholipase A activity as described below. There was no difference however, at least in growth rates, either as regards nutrient broth or minimal medium at $30^{\circ}$ between these mutants and the parent strains. As shown in Fig. 4, the enzyme from the parent cells hydrolyzed PE to liberate nearly the same amounts of free fatty acid and lyso-PE. On the other hand, the enzyme from the mutant cells failed to hydrolyze PE, and no free fatty acid was formed. Phospholipase $\mathrm{A}$ activities of these mutants were less than $2 \%$ of that of the parent strain (Table 5). In addition to the lack of phospholipase A activity, these mutants showed a partial defect in lysophospholipase activity (Table 5).

\section{Action of carotovoricin Er on the mutant}

Marked degradation of phospholipid was found when the cells of the parent strain were treated with the carotovoricin $\mathrm{Er}$ in $0.05 \mathrm{M}$ phosphate buffer, $\mathrm{pH}$ 7.2. Degradation of phospholipid was decreased when the cells were treated with the bacteriocin in the presence of $5 \mathrm{mM} \mathrm{MgCl}_{2}$ and the rate of degradation was about 


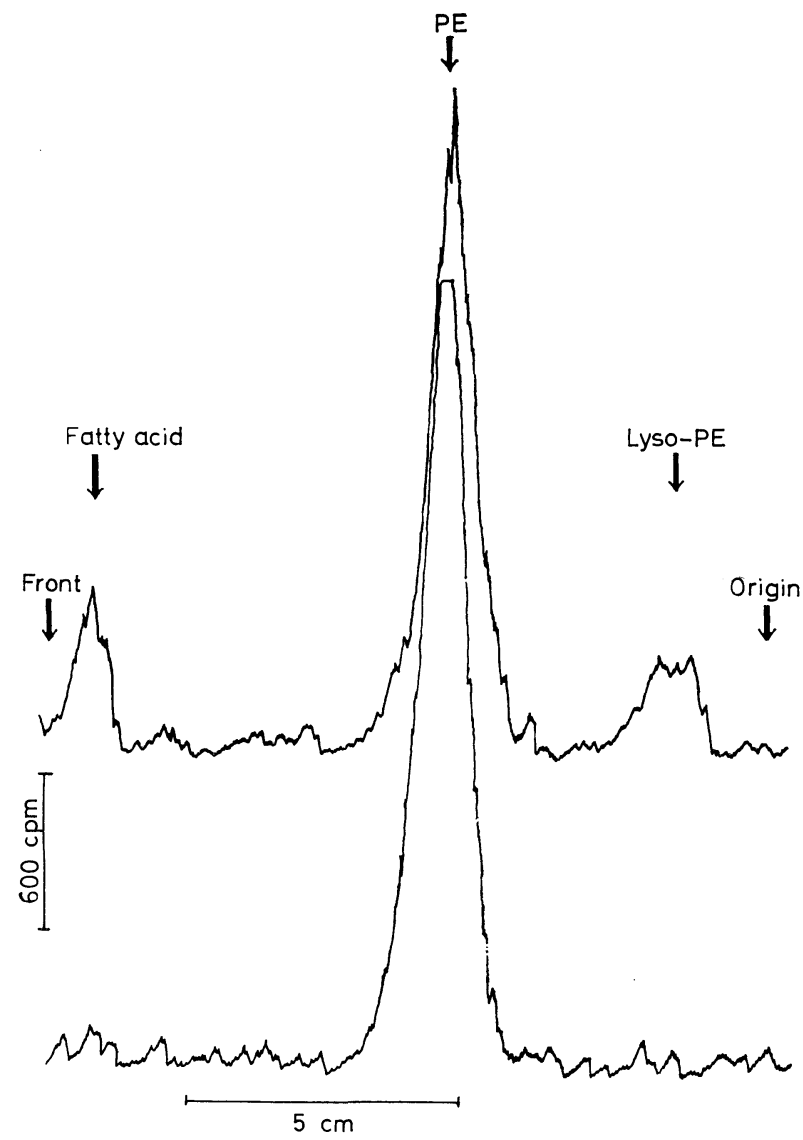

Fig. 4. Analysis of reaction products from phosphatidylethanolamine resulting from phospholipase A activity of E. carotovora $645 \mathrm{ArT}$ and its phospholipase A-deficient mutant (No. 1) by thin-layer chromatography.

The enzyme preparations (50 $\mu \mathrm{g}$ protein, each) from the parent and mutant strains were added to the phospholipase A assay mixture, and the reaction mixtures were incubated at $30^{\circ}$ for $30 \mathrm{~min}$. After the reaction, lipids were extracted and developed on a Silica gel thin-layer plate. Distribution of radioactivity was analyzed with an Aloka thin-layer chromatogram scanner. Reaction products resulting from phospholipase A activity from the parent strain (upper line) and phospholipase A-deficient mutant strain No. 1 (lower line) were indicated.

$1 / 7$ as much as that of the cells treated in the absence of $\mathrm{MgCl}_{2}(5)$. As shown in Fig. 5, degradation of phospholipid in mutant No. 1, which is deficient in phospholipase $\mathrm{A}$, was less than $1 / 10$ that of the parent cells even in the absence of $\mathrm{Mg}^{2+}$. On the other hand, when the mutant cells were treated with carotovoricin Er in the presence of $5 \mathrm{~mm} \mathrm{Mg}^{2+}$, no detectable amount of free fatty acid was released, at least within the 20 min following the addition of the bacteriocin (Fig. 5). The 


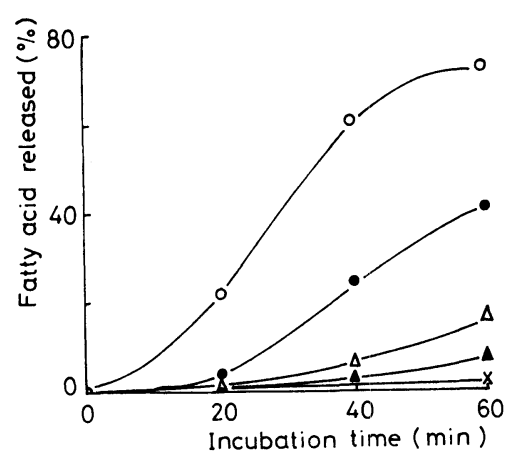

Fig. 5. Release of fatty acid in the cells of E. carotovora $645 \mathrm{ArT}$ and phospholipase A-deficient mutant treated with carotovoricin Er.

E. carotovora $645 \mathrm{ArT}$ and its phospholipase A-deficient mutant (No. 1) were grown in M9-glucose-casamino acid medium in the presence of $\left[1-{ }^{14} \mathrm{C}\right]$ acetate $(0.4 \mu \mathrm{Ci} / \mathrm{ml})$. The log-phase cells washed once with $\mathrm{M} 9$-buffer were suspended in $0.05 \mathrm{M} \mathrm{Na-K}$ phosphate buffer, pH 7.2 containing $0.15 \mathrm{M} \mathrm{NaCl}$ (buffer $\mathrm{A}$ ) or $0.01 \mathrm{M} \mathrm{Na}-\mathrm{K}$ phosphate buffer, $\mathrm{pH} 7.2$ containing $0.15 \mathrm{M} \mathrm{NaCl}$ and $5 \mathrm{mM} \mathrm{MgCl}_{2}$ (buffer B) at the cell concentration of $2 \times 10^{8}$ cells per $\mathrm{ml}$. Mixtures $(3 \mathrm{ml})$ containing $2.5 \mathrm{ml}$ of the cell suspension and $0.5 \mathrm{ml}$ of the bacteriocin solution ( 40 units $/ \mathrm{ml}$ ) or $0.5 \%$ of bovine serum albumin (control) were incubated at $30^{\circ}$. One-half $\mathrm{ml}$ of the mixture was withdrawn at various periods of incubation, and lipids were extracted by the method of BLIGH and DYER (6). Free fatty acid was separated from phospholipids by thin-layer chromatography with petroleum etherdiethyl ether-formic acid $(55: 40: 1.5, \mathrm{v} / \mathrm{v})$. The percentage radioactivities in the fatty acid fraction to the total radioactivity of phospholipids were plotted against incubation time with carotovoricin Er.

$\times$, E. carotovora $645 \mathrm{ArT}$, control in the buffer A; $\bigcirc$, E. carotovora 645ArT treated with carotovoricin $\mathrm{Er}$ in the buffer A; $\bullet$, E. carotovora $645 \mathrm{ArT}$ treated with carotovoricin Er in the buffer $\mathrm{B} ; \triangle$, the mutant treated with carotovoricin $\mathrm{Er}$ in the buffer $\mathrm{A} ; \boldsymbol{\Delta}$, the mutant treated with carotovoricin $\mathrm{Er}$ in the buffer B.

cell lysis of the sensitive strain induced by carotovoricin Er was found to be enhanced by phosphate and repressed by $\mathrm{Mg}^{2+}$ (4). The lysis caused by carotovoricin Er was also decreased in the mutant strain when the cells were treated with the bacteriocin in M9-medium in which the parent cells were lysed by the bacteriocin (Fig. 6-A). As shown in Fig. 6-B, a modified M9-medium containing a low concentration of phosphate $(10 \mathrm{~mm})$ and $5 \mathrm{~mm} \mathrm{MgCl}_{2}$ partially protected the parent strain from the lysis caused by the bacteriocin, while the modified M9-medium prevented the lysis of the mutant strains completely. Even in the modified M9-medium, growth of the mutant was inhibited by the bacteriocin, suggesting the mutant still retained the sensitivity to the bacteriocin. As shown in Fig. 7, the mutant strain showed the same sensitivity to carotovoricin Er as the parent strain. These results clearly indicate that phospholipase A of carotovoricin Er-sensitive cells is responsible for degradation of phospholipids and cell lysis caused by carotovoricin Er. 


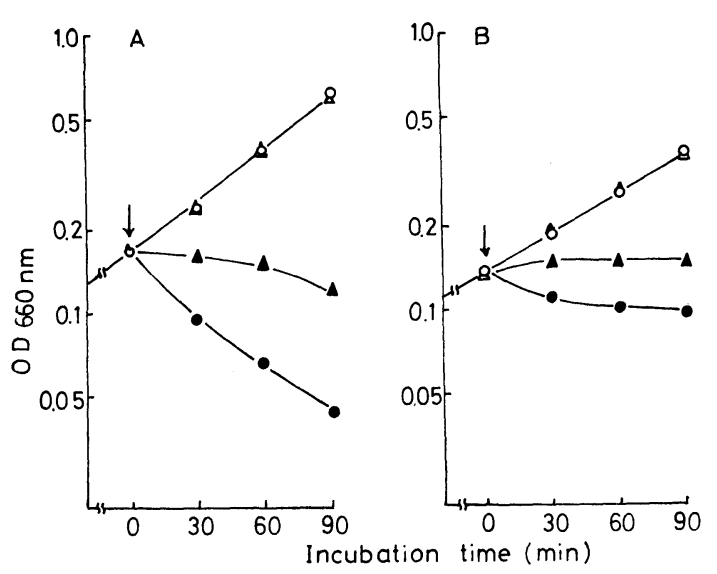

Fig. 6.

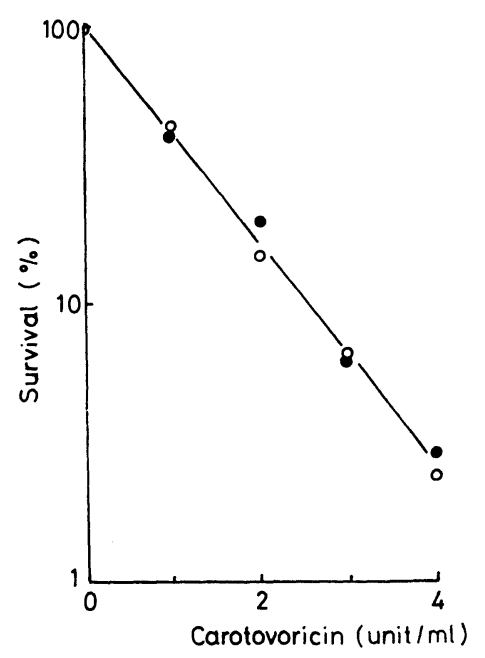

Fig. 7.

Fig. 6. Lysis of phospholipase A-deficient mutant after treatment with carotovoricin Er.

One-fifth $\mathrm{ml}$ of carotovoricin solution (100 units $/ \mathrm{ml})$ or $0.5 \%$ of bovine serum albumin was added to the early log-phase culture of E. carotovora 645ArT and phospholipase A-deficient mutant No. 1 as indicated by the arrows. These cultures were incubated at $30^{\circ}$ with shaking, and their optical density was measured with a Hitachi photoelectric colorimeter (FPW-4). A, M9-glucose-casamino acid medium; B, a modified M9-glucose-casamino acid medium in which phosphate was supplemented as $10 \mathrm{~mm} \mathrm{Na}-\mathrm{K}$ phosphate buffer, $\mathrm{pH} 7.2$, and $5 \mathrm{~mm} \mathrm{MgCl}_{2}$ was supplemented.

, E. carotovora $645 \mathrm{ArT}$ control; $\bullet$, E. carotovora $645 \mathrm{ArT}$ treated with carotovoricin Er; $\triangle$, the mutant control; $\Delta$, the mutant treated with carotovoricin Er.

Fig. 7. Susceptibility of E. carotovora 645ArT and phospholipase A-deficient mutant to carotovoricin Er.

log-phase cells grown in M9-glucose-casamino acid medium were washed once with M9 buffer, and suspended in $0.05 \mathrm{M} \mathrm{Na-K}$ phosphate buffer, $\mathrm{pH} 7.2$ containing $0.15 \mathrm{M}$ $\mathrm{NaCl}$ and $1.5 \times 10^{8}$ cells per $\mathrm{ml}$. Carotovoricin Er solution $(0.1 \mathrm{ml})$ was added to the cell suspensions $(0.4 \mathrm{ml})$ at final concentrations of zero to 4 units per $\mathrm{ml}$. The mixtures were incubated at $30^{\circ}$ for $20 \mathrm{~min}$, and viable cells were counted on nutrient agar medium.

O, E. carotovora 645ArT; •, phospholipase A-deficient mutant No. 1.

\section{DISCUSSION}

As demonstrated in this report, various properties of a major phospholipase A of E. carotovora $645 \mathrm{ArT}$ such as detergent- and heat-resistances, requirement of $\mathrm{Ca}^{2+}$ for optimal activity and location in the outer membrane, were similar to those of dr-phospholipase A of E. coli $(15,16)$. Dr-phospholipase A of E. coli has been demonstrated to have phospholipase $A_{1}, A_{2}$, lysophospholipase $L_{1}$, and $L_{2}$ activi- 
ties $(15,16)$. The specific site cleaved by phospholipase A of E. carotovora $645 \mathrm{ArT}$ has not been examined in detail. It was, however, suggested that the phospholipase A might also have lysophospholipase $\mathrm{L}_{1}$ activity, because the mutants deficient in phospholipase A showed an additional defect in lysophospholipase $\mathrm{L}_{1}$ activity as shown in Table 5 . About 60 to $70 \%$ of lysophospholipase $\mathrm{L}_{1}$ activity of the parental strain which was resistant to heating at $100^{\circ}$ for $10 \mathrm{~min}$ but sensitive to EDTA, was found in the membrane fraction. This lysophospholipase $\mathrm{L}_{1}$ activity would be attributed to the phospholipase $\mathrm{A}$, since the activity was not detected in the mutant deficient in the phospholipase A.

The mutant of E. carotovora $645 \mathrm{ArT}$ deficient in the phospholipase A isolated in this laboratory had no phospholipase A activity in vitro (Table 5). In spite of complete loss of the phospholipase A activity, this mutant could grow in nutrient broth and minimal medium as the parental strain (Fig. 6). A mutant of E. coli deficient both in dr-phospholipase A and ds (detergent sensitive)-phospholipase A has been reported to have no defect in growth, no alteration in turnover of polyglycerophosphatides and propagation of bacteriophages $(13,19,20)$. Hence, physiological functions of bacterial phospholipases remain unknown at present $(21,22)$. Our results with mutants deficient in phospholipase A demonstrate that hydrolysis of phospholipids in the cells affected by carotovoricin Er was catalyzed by phospholipase A in the sensitive cells. LUSK and PARK (23) have reported that the degradation product of PE in colicin K-treated E. coli was not detected in the dr-phospholipase A- and ds-phospholipase A-negative mutant although the sensitivity of the mutant to colicin $\mathrm{K}$ was the same as the parental strain. In phospholipase Adeficient mutant, free fatty acid was not detected at least within 20 min after challenge of carotovoricin Er (Fig. 5). A small amount of free fatty acid was found after further incubation. This is possibly due to the residual activity of the phospholipase A in vivo or other minor phospholipase A. We found another phospholipase A activity resembling that of ds-phospholipase A of E. coli (24) using ${ }^{14} \mathrm{C}$-phosphatidylglycerol as a substrate in the absence of detergent or methanol, although its activity was low ( 2 units/mg protein). Cell lysis induced by carotovoricin Er was also prevented in the phospholipase A-deficient mutant although growth of the cells ceased immediately after addition of carotovoricin Er to the culture medium (Fig. 6). This result indicates that the phospholipase A-deficient mutant still retained the sensitivity to the bacteriocin. The sensitivity of the mutant to carotovoricin Er was the same as that of the parent strain (Fig. 7). Our results clearly indicate that carotovoricin Er activates the latent phospholipase A to degrade the membrane phospholipids and leads the cells to lysis. We concluded that the ability of carotovoricin Er to induce the activation of phospholipase A might not be a primary bactericidal action. The phospholipase A-deficient mutant will be useful for study of the true bactericidal effect of carotovoricin Er on sensitive cells, because virtually no decomposition of the membrane occurs in the mutants infected by the bacteriocin. 
We are grateful to Prof. H. Tsuyama and Dr. H. R. Kaback for their kind donation of bacterial strains. We also thank Miss A. Sato of this faculty for her help in the operation of the liquid scintillation spectrometer and Dr. S. Okuda of this laboratory for his useful discussions. This investigation was supported in part by a Grant-in-Aid for Scientific Research (to H. T., 443026) from the Ministry of Education, Science, and Culture of Japan.

\section{REFERENCES}

1) P. ReEves, The Bacteriocins: Molecular Biology, Biochemistry, and Biophysics, Vol. 11, Springer-Verlag, New York (1972).

2) D. E. Bradley, Bacteriol. Rev., 31, 230 (1967).

3) Y. Itoh, K. Izaki, and H. TaKahashi, J. Gen. Appl. Microbiol., 24, 27 (1978).

4) Y. Itoh, K. Izaki, and H. TaKahashi, J. Gen. Appl. Microbiol., 26, 51 (1980).

5) Y. Itoh, K. Izaki, and H. Takahashi, J. Gen. Appl. Microbiol., 26, 85 (1980).

6) E. G. Bligh and W. J. Dyer, Can. J. Biochem. Physiol., 37, 911 (1959).

7) Y. Kanemasa, Y. Akamastu, and S. Nojima, Biochim. Biophys. Acta, 144, 382 (1967).

8) J. H. LAW and B. Essen, In Methods in Enzymology, Vol. 14, ed. by S. P. Colowick and N. O. Kaplan, Academic Press, New York (1969), p. 665.

9) G. R. Bartlett, J. Biol. Chem., 234, 466 (1959).

10) O. H. Lowry, N. J. Rosebrough, H. L. Farr, and R. J. Randall, J. Biol. Chem., 193, 265 (1951).

11) Y. KAmio and H. NiKaIdo, Biochemistry, 15, 2561 (1976).

12) H. H. TAuSKY and E. Shorr, J. Biol. Chem., 202, 675 (1953).

13) M. OHкI, O. DoI, and S. NoJima, J. Bacteriol., 110, 864 (1972).

14) E. A. Adelberg, M. Mandel, and G. C. C. Chen, Biochem. Biophys. Res. Commun., 18, 788 (1965).

15) M. Nishimura, S. Nakaike, Y. Tamori, and S. Nojima, Eur. J. Biochem., 73, 115 (1977).

16) C. J. Scandella and A. Kornberg, Biochemistry, 10, 4447 (1971).

17) D. A. White, F. A. Albright, W. J. Lennarz, and C. A. Schnaitman, Biochim. Biophys. Acta, 249, 636 (1971).

18) R. M. Bell, R. D. Mavis, M. J. Osborn, and P. R. Vagelos, Biochim. Biophys. Acta, 249, 628 (1971).

19) M. Аве, N. OKamoto, O. Dol, and S. Nojima, J. Bacteriol., 119, 543 (1974).

20) O. Doi and S. NoJima, J. Biochem., 80, 1247 (1976).

21) C. R. H. RaEtz, Microbiol. Rev., 42, 614 (1978).

22) H. V. D. Bosch, Biochim. Biophys. Acta, 604, 191 (1980).

23) J. E. Lusk and M. H. PARK, Biochim. Biophys. Acta, 394, 129 (1975).

24) O. Dor and S. Nojima, Biochim. Biophys. Acta, 260, 244 (1972). 